BIODIK: Jurnal IImiah Pendidikan Biologi
ISSN 2580-0922 (online), ISSN 2460-2612 (print)
Volume 6, Nomor 03, Tahun 2020, Hal. 336-351
Available online at:
https://online-journal.unja.ac.id/biodik

Research Article open 1 Access

\title{
Analisis Komponen Penyusun Desain Kegiatan Laboratorium Enzim Katalase
}

\author{
(Analysis of the Components of the Catalyst Enzyme Laboratory Design Activity)
}

\author{
Eka Astika*, Sri Anggraeni, Bambang Supriatno \\ Universitas Pendidikan Indonesia \\ J. Dr. Setiabudhi No.229, Cidadap, Isola, Sukasari, Kota Bandung, Jawa Barat 40154-Indonesia \\ ${ }^{*}$ Corresponding author : astikaeka47@gmail.com
}

\begin{tabular}{|c|c|}
\hline Informasi Artikel & ABSTRACT \\
\hline $\begin{array}{l}\text { Submit: } 02-06-2020 \\
\text { Diterima: } 28-08-2020 \\
\text { Dipublikasikan: } 11-09-2020\end{array}$ & $\begin{array}{l}\text { The purpose of this study is to : (a) obtain an overview of the } \\
\text { compatibility of the practical goals with the Basic Competencies } \\
\text { developed in the design of laboratorium activities, (b) obtain an } \\
\text { overview of the suitability of the practical goals and proceduaral steps } \\
\text { with the concept to be achieved, (c) find out whether the design of } \\
\text { laboratory activities used has supported knowledge construction } \\
\text { based on an analysis of the componets in the design of laboratory } \\
\text { activities. This research uses descriptive qualitative method through } \\
\text { the ANCOR stages, namely Analysis, Trial, and Reconstruction of five } \\
\text { catalase enzyme material laboratory design. The analysis carried out } \\
\text { includes an analysis of the arious activities listed in the worksheet so } \\
\text { that it can be seen how much these activities involve students in te } \\
\text { science process, their relevance to the applicable curriculum, the } \\
\text { relationship between the phenomena revealed and the concepts to be } \\
\text { achieved and construct student knowledge. The instrument used is } \\
\text { the modification of the instrument to analyze the suitability of pratikum } \\
\text { activities with the curriculum and Diagram Vee to see whether the } \\
\text { worksheet used constructs knowledge or not. The analysis included } \\
\text { conceptual analysis, pratical analysis and knowledge construction } \\
\text { analysis on various worksheet catalase enzyme tests. The catalase } \\
\text { enzyme test practicum emphasizes students' mastery of the catalase } \\
\text { enzyme test material that is both principle and procedural, where } \\
\text { students are required to be able to understand the properties of } \\
\text { enzymes, factors that influence the work of enzymes, and the role of } \\
\text { enzymes in metabolism. Thus it takes a series of competencies of } \\
\text { students' knowledge, skills and attitudes in mastering the catalase } \\
\text { enzyme test material. For this reason, it requires a worksheet design } \\
\text { that forms essential concepts so that they can achieve their goals and } \\
\text { are in line with the demands of Basic Competence. } \\
\text { Keywords: analysis of the components , design of laboratory } \\
\text { activities, catalase enzyme }\end{array}$ \\
\hline Penerbit & ABSTRAK \\
\hline $\begin{array}{l}\text { Program Studi Pendidikan } \\
\text { Biologi, Fakultas Keguruan dan } \\
\text { Ilmu Pendidikan, Universitas } \\
\text { Jambi }\end{array}$ & $\begin{array}{l}\text { Tujuan penelitian ini yaitu untuk: (a) memperoleh gambaran mengenai } \\
\text { kesesuaian tujuan pratikum dengan Kompetensi Dasar yang } \\
\text { dikembangkan dalam desain kegiatan laoratorium, (b) memperoleh } \\
\text { gambaran mengenai kesesuaian tujuan pratikum dengan langkah - } \\
\text { langkah prosedural dengan konsep yang akan dicapai, (c) } \\
\text { mengetahui apakah desain kegiatan laboratorium yang digunakan } \\
\text { sudah menunjang konstruksi pengetahuan berdasarkan analisis } \\
\text { komponen-komponen dalam desain kegiatan laboratorium. Penelitian } \\
\text { ini menggunakan metode deskriptif kualitatif melalui tahapan ANCOR }\end{array}$ \\
\hline
\end{tabular}


yaitu Analisis, Uji Coba, dan Rekonstruksi terhadap lima desain kegiatan laboratorium enzim katalase. Analisis yang dilakukan meliputi analisis terhadap ragam kegiatan yang tertera dalam LKS sehingga dapat diketahui seberapa besar kegiatan tersebut melibatkan siswa dalam proses sains, relevansinya dengan kurikulum yang berlaku, hubungan antara fenomena yang diungkap dengan konsep yang akan dicapai dan mengkonstruksi pengetahuan siswa. Instrumen yang digunakan adalah modifikasi instrumen untuk menganalisis kesesuaian kegiatan pratikum dengan kurikulum dan Diagram Vee untuk melihat apakah desain kegiatan laboratorium yang digunakan mengkonstruksi pengetahuan atau tidak. Analisis yang dilakukan meliputi analisis konseptual, analisis pratikal dan analisis konstruksi pengetahuan pada berbagai LKS uji enzim katalase. Pratikum uji enzim katalase menekankan pada penguasaan siswa terhadap materi uji enzim katalase yang bersifat prinsip serta prosedural, dimana siswa dituntut untuk mampu memahami sifat-sifat enzim, faktor-faktor yang mempengaruhi kerja enzim, serta peran enzim didalam metabolisme. Dengan demikian dibutuhkan serangkaian kompetensi pengetahuan, keterampilan, dan sikap siswa dalam menguasai materi uji enzim katalase. Untuk itu dibutuhkan desain LKS yang membentuk konsep - konsep esensial sehingga dapat mencapai tujuan dan sejalan dengan tuntutan Kompetensi Dasar.

Katakunci: analisis komponen, desain kegiatan laboratorium, enzim katalase

This BIODIK : Jurnal IImiah Pendidikan Biologi is licensed under a CC BY-NC-SA (Creative Commons Attribution-ShareAlike 4.0 International License)

\section{PENDAHULUAN}

Salah satu tujuan pembelajaran biologi seperti yang tercantum dalam Permendikbud No. 36 Tahun 2018 adalah memberikan pengalaman kepada peserta didik pada metode ilmiah dan aspek keselamatan kerja dengan mempraktekkan metode ilmiah melalui tahapan pengamatan dan percobaan atau eksperimen, dimana peserta didik melakukan pengujian hipotesis dengan merancang melakukan, mengolah data, dan mengomunikasikan hasil eksperimen secara lisan dan tulisan untuk menumbuhkan pola pikir ilmiah sebagai bekal dalam kehidupan di abad 21 . Tujuan tersebut pada dasarnya menghendaki agar pelajaran biologi mengajak siswa untuk melakukan kegiatan pratikum. Kegiatan pratikum merupakan komponen esensial dari belajar dan mengajar sains, baik untuk tujuan mengembangkan pengetahuan ilmiah siswa maupun mengembangkan pengetahuan siswa tentang sains (Millar, 2004). Berkaitan dengan tuntutan kurikulum, konsep yang dikembangkan hendakya mengarah pada penguasaan materi yang essensial, bahkan merupakan bagian kecil dari konsep yang harus dikuasai (Suprianto, 2013).

Sebagai pendekatan pengajaran khusus dan lingkungan belajar, kegiatan pratikum telah digunakan dengan berbagai tujuan, biasanya tujuan tersebut diambil dari dalam dokumen kurikulum dan dalam berbagai literatur. Dalam ulasan komprehensif Hofstein dan Lunetta (Wei \& Li , 2017) meringkas tujuan ini menjadi lima kategori : (1) pemahaman tentang konsep ilmiah; (2) minat dan motivasi; (3) keterampilan praktis ilmiah dan kemampuan memecahkan masalah; (4) kebiasaan 
berpikir ilmiah (lebih baru); dan (5) pemahaman dari sifat ilmu. Sedangkan tujuan guru dalam melakukan pratikum dapat diklasifikasikan ke dalam : konseptual, prosedural dan afektif domain (Sani, 2013).

Menurut Millar \& Abrahams (2007) agar kegiatan pratikum menjadi efektif maka ada dua efektivitas yang dikembangkan dalam kegiatan belajar mengajar, (1) tujuan pratikum harus jelas menggambarkan apa yang harus dipelajari siswa, sehingga siswa tahu apa yang sebenarya harus dipelajari. (2) jika tujuannya sudah sesuai maka apa yang harus dikerjakan siswa atau langkah-langkah kerjanya juga harus sesuai sehingga didalam kegiatan pratikum siswa memahami apa yang sebenarnya dikerjakan. Tiberghien (2000) dalam Millar \& Abrahams (2007) mencirikan kegiatan laboratorium sebagai upaya membantu siswa membuat hubungan antara dua domain pengetahuan yaitu domain objek dan yang dapat diamati serta domain ide.

Pada saat melaksanakan pratikum di sekolah, siswa mungkin tertarik untuk membuat catatan mengenai kejadian atau objek yang diobservasinya. Siswa dapat mengubah catatan menjadi grafik, tabel, atau diagram dan gambaran kesimpulan atau perolehan pengetahuan tanpa siswa sadar apa yang telah mereka kerjakan. Siswa tanpa sadar tidak menggunakan konsep, prinsip, dan teori yang relevan untuk memahami objek/kejadian yang sedang diobservasi selama kegiatan pratikum. Hal ini menyebabkan ketidabermaknaan dalam melakukan pratikum (Novak \& Gowin, 1985).

Desain LKS yang merupakan salah satu perangkat pembelajaran yang disusun guna memberikan panduan kegiatan belajar bagi siswa diharapkan dapat mengembangkan kemampuan metakognitif siswa, karena siswa dapat menghubungkan proses berfikirnya dengan pratikum yanng dilakukan. Suatu instrumen yang dapat memperlihatkan hubungan proses berfikir siswa dengan pratikum yang dilakukannya adalah menggunakan Diagram Vee. Sebagaimana yang diungkapkan oleh Novak \& Gowin (1985), bahwa diagram Vee adalah sebuah alat untuk memperoleh pengetahuan tentang pengetahuan bagaimana pengetahuan dapat dibangun dan digunakan.

Rustaman \& Wulan (2007) mengungkapkan bahwa guru harus mencoba terlebih dahulu kegiatan yang harus dilakukan. Guru pun harus meneliti terlebih dahulu potensi keterlaksanaan dan ketercapaian dari sebuah desain kegiatan laboratorium. Hal ini dianggap perlu karena tak jarang guru menggunakan sebuah desain kegiatan laboratorium seperti halnya sebuah resep. Padahal, analisis desain kegiatan laboratorium juga harus dilaksanakan guru sebelum desain kegiatan laboratorium tersebut diuji coba oleh siswa. Hal ini dinilai penting untuk dilakukan untuk menghindari kegagalan praktikum karena guru masih mungkin memperbaiki prosedur, bahan, dan peralatan yang kurang sesuai.

Menurut Woolnough dan Allsop (Supriatno, 2013), kerja praktek bertujuan memotivasi, mengembangkan tekhnik dan keterampilan eksperimen; belajar pendekatan ilmiah; meningkatkan aspek pemahaman teoritis dari mata pelajaran. Kualitas kerja praktek yang baik akan membantu siswa menjadi lebih aktif pada saat belajar sains, melatih kemampuan inkuiri, mengumpulkan data dan fakta, sistematis 
dalam mendeskripsikan objek, membuktikan teori dan prinsip, mengajukan pertanyaan, melakukan Discovery, dan mengkomunikasikan temuannya (Laelasari, 2018).

Kegiatan praktikum materi uji enzim katalase merupakan topik konten yang diberikan pada siswa kelas XII IPA SMA semester satu. Praktikum uji enzim katalase menekankan pada penguasaan siswa terhadap materi uji enzim katalase yang bersifat prinsip serta prosedur, dimana siswa dituntut untuk mampu memahami sifatsifat enzim, faktor-faktor yang mempengaruhi kerja enzim, serta peran enzim didalam metabolisme. Dengan demikian dibutuhkan serangkaian kompetensi pengetahuan, keterampilan, dan sikap siswa dalam menguasai materi uji enzim katalase. Untuk itu dibutuhkan desain kegiatan laboratorium yang membentuk konsep - konsep esensial sehingga dapat mencapai tujuan dan sejalan dengan tuntutan Kompetensi Dasar (KD).

Oleh karena itu dalam penelitian ini akan dilakukan analisis desain, ditekankan pada perangkat pembelajaran yang berupa LKS. Persoalan dalam penelitian ini adalah: (a) apakah tujuan pratikum pada desain kegiatan laboratorium sesuai dengan Kompetensi Dasar (KD)?, (b) apakah langkah - langkah pada desain kegiatan laborratorium uji enzim katalase sesuai dengan tujuan pratikum?, (c) apakah komponen-komponen dalam desain kegiatan laboratorium mengkonstruk pengetahuan siswa?

Adapun tujuan penelitian yaitu untuk mengetahui: (a) memperoleh gambaran mengenai kesesuaian tujuan pratikum dengan Kompetensi Dasar yang dikembangkan dalam desain kegiatan laboratorium, (b) memperoleh gambaran mengenai kesesuaian tujuan pratikum dengan langkah - langkah prosedural dengan konsep yang akan dicapai, (c) mengetahui apakah kegiatan didalam desain kegiatan laboratorium mengkonstruk pengetahuan siswa berdasarkan dari analisis komponenkomponen dalam desain kegiatan laboratorium. Pentingnya dilakukan analisis isi pada praktikum ini didasari bahwa proses kegiatan praktikum memberikan gambaran mengenai komponen tujuan, proses, dan pertanyaan dalam desain kegiatan laboratorium, dan dapat digunakan sebagai rujukan dalam melakukan modifikasi dan rekonstruksi dalam rangka memperbaiki kualitas suatu proses kegiatan laboratorium menggunakan desain kegiatan laboratorium konsep cara kerja enzim.

\section{METODE PENELITIAN}

Penelitian ini merupakan penelitian deskriptif kualitatif melalui tahapan ANCOR yaitu Analisis, Uji Coba, dan Rekonstruksi terhadap lima desain kegiatan laboratorium materi enzim katalase. Analisis yang dilakukan meliputi analisis terhadap ragam kegiatan yang tertera dalam lembar kerja siswa atau desain kegiatan laboratorium sehingga dapat diketahui seberapa besar kegiatan tersebut melibatkan siswa dalam proses sains, relevansinya dengan kurikulum yang berlaku, hubungan antara fenomena yang diungkap dengan konsep yang akan dicapai dan mengkonstruksi pengetahuan siswa.

Kegiatan pengembangan laboratorium diawali dengan menganalisis DKL yang diterbitkan oleh penerbit, menguji coba, merekonstruksi atau membuat desain 
kegiatan laboratorium (DKL) yang baru (Supriatno, 2013). Untuk melihat kelemahan desain kegiatan laboratorium maka perlu dilakukan analisis khususnya pengetahuan prosedural dan konseptualnya. Selanjutnya DKL yang telah dianalisis di ujicobakan oleh guru dengan mengikuti langkah-langkah prosedural sebelum diterapkan kepada siswa, untuk mengetahui apakah DKL tersebut dapat dilakukan siswa atau tidak. Apabila terjadi kegagalan keterlaksanaan laboratorium dari desain kegiatan yang tidak tepat maka akan dilakukan rekonstruksi untuk mengubah sebagian atau keseluruhan dari DKL tersebut karena mengandung kesalahan atau hasil eksekusi prosedur yang kurang tepat.

Obyek penelitian adalah lembar kerja siswa untuk pratikum kerja enzim katalase yang digunakan di SMA se Kabupaten Rokan Hilir Propinsi Riau. Lembar kerja siswa tersebut berasal dari beberapa buku pegangan siswa yang diterbitkan oleh beberapa penerbit. Sebanyak 5 LKS yang diterbitkan oleh penerbit tersebut diberi kode: ER, IP-1, ES, IP-2 dan QU. Penelitian ini dilaksanakan pada bulan Februari sampai dengan Maret 2020 yang dilaksanakan di FMIPA UPI. Dalam penelitian ini instrumen yang dipergunakan hasil modifikasi instrumen berupa Form Analisis Kegiatan Laboratorium dan diagram Vee yang diungkapkan Novak \& Gowin (1985), mengandung skor yang telah ditentukan. Selanjutnya persentase yang diperoleh dari diagram Vee di interpretasikan datanya berdasarkan Arikunto (2008).

\section{HASIL DAN PEMBAHASAN}

Sebelum menguji cobakan kegiatan praktikum, peneliti perlu menganalisis LKS yang diterbitkan oleh penerbit, yaitu analisis konseptual, pratikal dan konstruksi penegtahuan. Dalam analisis konseptual dilakukan untuk menentukan kesesuaian konten, kompetensi, judul, tujuan, langkah kerja, tingkat kognitif siswa dengan kurikulum yang berlaku. Analisis pratikal bertujuan untuk menguji keterlaksanaan kegiatan secara laboratorium dalam menghadirkan objek/fenomena. Analisis konstruksi pengetahuan dibentuk berdasarkan objek/fenomena yang muncul, dicatat dan digunakan untuk mengkontruksi pengetahuan. Tanpa adanya analisis dan perencanaan yang baik, maka kegiatan praktikum tidak akan berjalan dengan baik dan tujuan pembelajaran tidak akan tercapai. Hasil analisis dari kelima LKS tersebut dapat lihat pada tabel 1.

Tabel 1. Analisis Konseptual kesesuaian dengan kurikulum pada ragam LKS

\begin{tabular}{llllll}
\hline $\begin{array}{c}\text { Ragam } \\
\text { LKS }\end{array}$ & \multicolumn{5}{c}{ Kesesuaian dengan Kurikulum } \\
\cline { 2 - 6 } & $\begin{array}{c}\text { Konten } \\
\text { dengan KD }\end{array}$ & $\begin{array}{c}\text { Kompetensi } \\
\text { dengan KD }\end{array}$ & $\begin{array}{c}\text { Judul dengan } \\
\text { kegiatan }\end{array}$ & $\begin{array}{c}\text { Tujuan } \\
\text { dengan } \\
\text { langkah kerja }\end{array}$ & $\begin{array}{c}\text { Kegiatan dengan } \\
\text { tingkat kognitif } \\
\text { siswa }\end{array}$ \\
\hline ER & Sesuai & Sesuai & Tidak sesuai & Tidak sesuai & Sesuai \\
IP-1 & Sesuai & Sesuai & Sesuai & Tidak sesuai & Sesuai \\
ES & Sesuai & Sesuai & Tidak sesuai & Sesuai & Sesuai \\
IP-2 & Sesuai & Sesuai & Sesuai & Tidak sesuai & Sesuai \\
QU & Sesuai & Sesuai & Tidak sesuai & Tidak sesuai & Sesuai \\
\hline
\end{tabular}

Jika dilihat dari kegiatan laboratorium yang dianalisis secara umum sudah sesuai dengan kurikulum yang berlaku baik konten, kompetensi maupun kesesuaian 
dengan tingkat kognitif siswa. Tetapi untuk kesesuaian kegiatan dengan judul LKS hanya $40 \%$, sedangkan $60 \%$ LKS yang beredar di sekolah-sekolah masih belum sesuai antara judul dengan kegiatan yang terdapat dalam LKS.Ketidaksesuaian antara antara tujuan dengan langkah kerja juga hanya $20 \%$, sisa sebanyak $80 \%$ masih tidak sesuai antara tujuan dengan langkah kerja yang terdapat dalam LKS yang dianalisis. Hal ini menyebabkan siswa masih bingung dalam mengambil data dan menarik kesimpulan dari kegiatan yang dilakukan. Menurut Laelasari (2019) hanya $20 \%$ tujuan praktikum mengacu pada indikator hasil penjabaran Kompetensi Dasar, tergambar dalam langkah kerja dan dapat dicapai setelah melakukan kegiatan laboratorium. Sisanya sebanyak $80 \%$ bermasalah dalam hal tidak tergambarnya tujuan dalam langkah kerja dan tidak dapat dicapainya tujuan praktikum. Hampir $80 \%$ proses kegiatan pratikum tidak mengacu pada tujuan, tidak logis, struktur langkah kerjanya tidak sistematis, serta tidak dapat menghasilkan data yang diharapkan.

Menurut Millar (2004) keefektifan/ efektivitas suatu kerja praktikum dapat diukur dari segi (1) prosedur kegiatan, yakni berkaitan dengan apa yang dikerjakan siswa, dan (2) hasil kerja praktikum, dalam hal ini berkaitan dengan apa yang dipelajari siswa Efektivitas langkah kerja yang dimaksud merupakan terlaksananya langkah/ prosedur kerja dalam desain kegiatan laboratorium dan juga dapat menghasilkan data/fakta yang diharapkan. Menurut Supriatno (2009) adanya langkah kerja yang salah dalam suatu LKS dapat mengakibatkan tingkat efektivitas kerja menjadi berkurang. Apabila efektivitas kerja berkurang, maka pada dasarnya siswa banyak mengerjakan yang tidak seharusnya dikerjakan. Dengan demikian siswa belajar tidak mengenai apa yang seharusnya dipelajari. Untuk melihat keefektifan tujuan pratikum dapat dilihat melalui analisis pratikalnya seperti pada tabel 2.

Tabel 2. Analisis Pratikal pada Ragam LKS

\begin{tabular}{|c|c|c|c|c|c|}
\hline \multirow[t]{2}{*}{ Parameter } & \multicolumn{5}{|c|}{ Ragam LKS } \\
\hline & ER & IP-1 & ES & IP-2 & QU \\
\hline Alat-alat sesuai dengan standar/tersedia & $\sqrt{ }$ & $\sqrt{ }$ & $\sqrt{ }$ & $\sqrt{ }$ & $\sqrt{ }$ \\
\hline Bahan pratikum dapat diediakan dengan mudah & $\sqrt{ }$ & $\sqrt{ }$ & $\sqrt{ }$ & $\sqrt{ }$ & $\sqrt{ }$ \\
\hline Langkah-langkahnya terstruktur & $\sqrt{ }$ & $\sqrt{ }$ & $\sqrt{ }$ & $\sqrt{ }$ & $\mathrm{x}$ \\
\hline Setiap langkah dapat diekseskusi tanpa kesulitan & $\mathrm{x}$ & $\mathrm{x}$ & $x$ & $\mathrm{x}$ & $\mathrm{x}$ \\
\hline Objek/fenomenanya muncul & $\mathrm{x}$ & $\mathrm{x}$ & $\sqrt{ }$ & $\mathrm{x}$ & $\mathrm{x}$ \\
\hline Objek/fenomena mudah diamati & $x$ & $\mathrm{x}$ & $x$ & $x$ & $\mathrm{x}$ \\
\hline Ada perekaman data & $\sqrt{ }$ & $\sqrt{ }$ & $\sqrt{ }$ & $\sqrt{ }$ & $\sqrt{ }$ \\
\hline Bentuk perekaman objek/fenomena & $\sqrt{ }$ & $\sqrt{ }$ & $\sqrt{ }$ & $\sqrt{ }$ & $\sqrt{ }$ \\
\hline Objek fenomena relevan dengan judul/tujuan & $\mathrm{x}$ & $\mathrm{x}$ & $\mathrm{x}$ & $\mathrm{x}$ & $\mathrm{x}$ \\
\hline Waktu yang digunakan & $\sqrt{ }$ & $\sqrt{ }$ & $\sqrt{ }$ & $\sqrt{ }$ & $\sqrt{ }$ \\
\hline Petunjuk safety lab & $\sqrt{ }$ & $\sqrt{ }$ & $\sqrt{ }$ & $x$ & $x$ \\
\hline Ketepatan prosedur & $\mathrm{x}$ & $\mathrm{x}$ & $x$ & $x$ & $x$ \\
\hline
\end{tabular}

Alat dan bahan pada kelima LKS secara umum sesuai dengan standar dan mudah ditemukan. Hanya pada LKS QU yang memiliki langkah kerja yang tidak terstruktur dengan baik. Dalam kegiatan pratikum terdapat langkah kerja yang sulit 
dieksekusi atau kurang efisien seperti pada LKS ER, IP-1, IP-2 dan QU terdapat langkah kerja yang sulit dilakukan yaitu membuat ekstrak hati kemudian dimasukkan kedalam tabung reaksi. Sedangkan untuk LKS ES dalam prosedur yang sulit dilaksanakan adalah membuat pengenceran $\mathrm{H}_{2} \mathrm{O}_{2}$ dengan berbagai konsentrasi tidak disebutkan berapa $\mathrm{ml}$ sehingga banyak larutan yg terbuang. Objek/fenomena muncul pada kegiatan pratikum LKS ES tetapi sangat sulit untuk diamati. Sedangkan pada LKS yg lainnya objek/fenomena tidak muncul maka tidak ada objek/fenomena yang dapat diamati. Sehingga objek/fenomena tersebut tidak relevan dengan tujuan/judul. Objek/fenomena tersebut tidak muncul kerena prosedur yang kurang tepat. Hasil tersebut sesuai dengan apa yang dijelaskan Supriatno (2009) bahwa apabila siswa mengerjakan langkah kerja yang tidak terstruktur ataupun ambigu (membingungkan) maka dapat mengakibatkan kegagalan dalam proses laboratorium yang dilakukan. Kegagalan ini dikarenakan tidak diperolehnya data yang diharapkan untuk membantu siswa dalam menyimpulkan. Apabila prosedur kegiatan salah, maka pada dasarnya siswa belajar pengetahuan yang salah dan hal ini dapat memicu timbulnya miskonsepsi bagi siswa. Dikaji dari aspek analisis konstruksi pengetahuaannya maka dapat dilihat pada tabel 3.

Tabel 3. Analisis Konstruksi Pengetahuan

\begin{tabular}{|c|c|c|c|c|c|}
\hline \multirow[t]{2}{*}{ Parameter } & \multicolumn{5}{|c|}{ Ragam LKS } \\
\hline & ER & IP-1 & ES & IP-2 & QU \\
\hline Pertanyaan semua dapat dijawab tanpa pratikum & $x$ & $\mathrm{x}$ & $\mathrm{x}$ & $\sqrt{ }$ & $\sqrt{ }$ \\
\hline Menanyakan karakter fakta yang muncul & $\sqrt{ }$ & $\sqrt{ }$ & $\sqrt{ }$ & $\sqrt{ }$ & $\sqrt{ }$ \\
\hline Fakta digunakan untuk mengkontruksi konsep & $\sqrt{ }$ & $x$ & $\sqrt{ }$ & $x$ & $\sqrt{ }$ \\
\hline Ada proses interpretasi data & $\sqrt{ }$ & $\sqrt{ }$ & $\sqrt{ }$ & $\sqrt{ }$ & $\sqrt{ }$ \\
\hline Ada pertanyaan terkaitkemunculan suatu konsep & $\sqrt{ }$ & $\sqrt{ }$ & $\sqrt{ }$ & $x$ & $x$ \\
\hline Ada pertanyaan terkait analisis & $\sqrt{ }$ & $x$ & $\sqrt{ }$ & $\sqrt{ }$ & $x$ \\
\hline $\begin{array}{l}\text { Penarikan kesimpulan berdasarkan data yang } \\
\text { direkam }\end{array}$ & $\sqrt{ }$ & $\sqrt{ }$ & $\sqrt{ }$ & $\sqrt{ }$ & $\sqrt{ }$ \\
\hline $\begin{array}{l}\text { Kesimpulan yang dibangun menggambarkan } \\
\text { judul/tujuan }\end{array}$ & $\sqrt{ }$ & $\sqrt{ }$ & $x$ & $x$ & $\mathrm{x}$ \\
\hline
\end{tabular}

Pertanyaan yang tidak mengacu pada tujuan dan proses, pada umumnya merupakan pertanyaan yang sama sekali tidak berhubungan dengan langkah kerja, serta tidak dapat mengarahkan pada pencapaian tujuan yang diharapkan. Hasil analisis diatas menegaskan bahwa komponen pertanyaan yang ada dalam desain kegiatan laboratorium harus bersesuaian dengan proses yang dilakukan dan tujuan yang ingin dicapai, sehingga siswa dapat menjawab pertanyaan yang tercantum melalui data yang telah mereka kumpulkan. Hal ini sesuai dengan penjelasan Rustaman \& Wulan (2007) bahwa pertanyaan yang ada hendaknya dapat menuntun siswa pada pokok persoalan, dan dapat dijawab oleh siswa. Dalam hal ini pertanyaan dapat digunakan untuk mengukur ketercapaian proses dan tujuan, menuntun praktikan untuk memahami konsep yang dipelajari dan mengarahkan praktikan untuk membuat suatu kesimpulan yang tepat. 


\section{Analisis Keberadaan dan Penskoran Komponen Diagram Vee}

Setelah dilakukan analisis keberadaan komponen diagram Vee, dilakukan pula penskoran setiap komponen diagram Vee. Hasil temuan pada Tabel 4 menunjukkan bahwa meskipun pada LKS sudah terdapat komponen diagram Vee, namun skor yang didapatkan setiap komponennya masih rendah.

Tabel 4. Analisis Penerapan Komponen Diagram Vee

\begin{tabular}{|c|c|c|c|c|c|}
\hline \multirow{2}{*}{$\begin{array}{l}\text { Komponen } \\
\text { Diagram Vee }\end{array}$} & \multicolumn{5}{|c|}{ Skor yang diperoleh pada ragam LKS } \\
\hline & ER & IP-1 & ES & IP-2 & QU \\
\hline Focus Question & 2 & 2 & 2 & 2 & 1 \\
\hline Object/Event & 0 & 0 & 1 & 0 & 0 \\
\hline $\begin{array}{l}\text { Teori, Prinsip dan } \\
\text { Konsep }\end{array}$ & 2 & 2 & 2 & 2 & 1 \\
\hline Records/Pencatatan & 0 & 0 & 0 & 0 & 0 \\
\hline Knowledge & 2 & 2 & 2 & 2 & 2 \\
\hline Total Skor & 6 & 7 & 7 & 6 & 4 \\
\hline
\end{tabular}

Perolehan skor pertanyaan fokus pada LKS ER, IP-1, ES dan EP-2 menunjukkan skor 2 yang artinya Pertanyaan fokus dapat diidentifikasi serta mengandung bagian konseptual tetapi tidak mendukung kepada observasi objek atau peristiwa utama. LKS QU memperoleh skor 1 yang artinya Pertanyaan fokus dapat diidentifikasi, tetapi tidak memfokuskan kepada hal utama yang berkaitan dengan objek dan peristiwa atau tidak mengandung bagiankonseptual. Untuk objek/event, perolehan skor pada pada LKS ER, IP-1, IP-2 dan QU menunjukkan skor 0 yang artinya tidak ada Objek/peristiwa yang dapat diidentifikasi.

Untuk LKS ES memperoleh skor 1 yang artinya Peristiwa utama atau objek dapat diidentifikasi dan konsisten dengan pertanyaan fokus, atau peristiwa dan objekdapatdiidentifikasi,tetapitidakkonsistendengan pertanyaan fokus. Untuk teori, prinsip dan konsep, LKS ER, IP-1, ES dan IP-2 memperoleh skor 2 yang artinya terdapat konsep dan setidaknya satu jenis prinsip (konseptual dan metodologis) atau konsep dan teori yang relevan dapat diidentifikasi. Sedangkan pada LKS QU menunjukkan skor 1, yang artinya Sedikit konsep yang dapat diidentifikasi, tetapi tanpa prinsip-prinsip serta teori, atau sebuah prinsip yang tertulis merupakan pengetahuan yang diperoleh dari kegiatan laboratorium.

Untuk catatan/transformasi, perolehan skor pada semua ragam LKS menunjukkan skor 0 yang artinya tidak ada catatan atau transformasi yang dapat diidentifikasi. Jika pada praktikum tidak terjadi proses pencatatan dan transformasi data, maka klaim pengetahuan yang dilakukan bisa menjadi salah atau tidak relevan dengan sisi konseptual Vee. Ini artinya pada ragam LKS tersebut pada umumnya terdapat teori, prinsip serta konsep yang dapat memberikan dasar pada siswa untuk mengkonstruk pengetahuan barunya atau sebagai dasar untuk pembelajaran lebih lanjut (Swami \& Shield, 2006). Untuk klaim pengetahuan, skor yg diperoleh 2 yang artinya perolehan pengetahuan tidak sesuai bagian kiri diagram Vee, kecuali pada LKS QU memperoleh skor 1 yang artinya Tidak ada perolehan pengetahuan yang dapat diidentifikasi. Pengetahuan klaim mencakup konsep yang digunakan dalam konteks yang tidak tepat atau generalisasi yang tidak konsisten dengan catatan dan 
transformasi. Ini terjadi karena tidak adanya kegiatan pencatatan data dan atau transformasi data yang didapatkan dalam kegiatan praktikum. Konsep biologi ditemukan melalui proses sains yang dapat dikategorikan sebagai kegiatan penginderaan(menggunakan indera), motorik (menggunakan alat gerak), dan kemampuan berpikir(menggunakan otak/pemikiran).

Kegiatan Tersebut merupakan rangkaian yangtak dapat dipisahkan dan menggunakan polapikir tertentu. Pola berpikir sains oleh Frankmaupun Reece et al (2011), dirumuskansebagai proses berpikir induktif-deduktifyang berkesinambungan. Oleh karena itu selayaknya kegiatan siswa dengan menggunakanLKS memberikan peluang yang besar untukmelakukan penginderaan terhadap gejala padaobyek biologi supaya dapat membangun konsepsendiri.

Di lain kesempatan siswa diberipeluang untuk melakukan verifikasi faktafaktayang mendukung konsep tertentu. Dengandemikian siswa selalu terlibat dalamproses berpikir induktif-deduktif yag bersifatsiklik. Berdasarkan temuan di atas tampak belumsemua LKS mengacu pada pola pikir induktif-deduktif. LKS semestinya memberikesempatan pada siswa untuk lebih mengenal obyek biologi dan gejalanya. Pernyataan ataupersepsi tentang makhluk hidup dan fenomenanyajika diformulasikan berupa produk ilmiah,yang kemudian kita kenal sebagai konsep,teori, prinsip, dan hukum dalam biologi.Semua ini merupakan produk, yaitu berupa ilmuatau sering disebut dengan bangunan ilmu(the body of knowledge). Bangunan ilmu tersebutoleh Lawson digolongkan sebagai knowledge of scientific products yaitu berupa:fakta-fakta, konsep-konsep, dan teori-teori (Lawson, A.E., 1995). Jika fenomenayang diamati amat terbatas dapat dipastikan konsep yang dibangun siswa menjadi tidaksempurna, dan kemungkinan dapat terjadi miskonsepsi. Diagram Vee pada masing-masing LKS dapat dilihat pada tabel 5.

Tabel 5. Persentase Keberadaan Diagram Vee

\begin{tabular}{lllll}
\hline \multicolumn{1}{r}{ Ragam LKS } & & Skor Total & & Persentase \\
\hline ER & 6 & & $33 \%$ & Kriteria \\
IP-1 & 7 & $39 \%$ & Kurang \\
ES & 7 & $39 \%$ & Kurang \\
IP-2 & 6 & $33 \%$ & kurang \\
QU & 4 & $2 \%$ & Kurang \\
\hline
\end{tabular}

Berdasarkan tabel diatas skor total dari masing-masing LKS belum mencapai skor ideal (100\%). Hal ini menunjukkan bahwa LKS yang digunakan di berbagai SMA masih kurang dalam mengkonstruk pengetahuan baru bagi siswa. LKS yang seharusnya terdapat teori, prinsip serta konsep yang dapat memberikan dasar pada siswa untuk mengkonstruk pengetahuan barunya masih kurang dalam hal meningkatkan kemampuan kognitif siswa sesuai dengan kompetensi dasar yang diharapkan.

Dalam hal ini Carin \& Sund (1989) menunjukkan beberapa contoh LKS yang bersifat inquiry oriented. Dalam contoh tersebut nampak struktur LKS yang menggambarkan langkah-langkah proses ilmiah yang lengkap mulai dari perumusan masalah sampai menemukan masalah baru. Jika siswa terbiasa melakukan kegiatan belajar dengan menggunakan kaidah proses ilmiah yang benar, maka semua ranah 
baik kognitif, afektif, sensori motorik dan keterampilan sosial diharapkan dapat berkembang.

Dalam menyusun desain kegiatan laboratorium seorang guru harus memahami hirarkhi berpikir siswa, mulai dari yang sederhana sampai dengan yang kompleks. Hal tersebut dapat diterapkan jika akan mengembangkan ragam proses sainsnya maupun dalam hal menyusun pertanyaan dalam arahan diskusi dalam LKS.Menurut Carin \& Sund (1975) bahwa ragam investigasi dalam sains meliputi beberapa hal: (a) observasional, (2) klasifikasional, dan (3) eksperimental. Oleh karenanya jika akan menuntun siswa supaya runtut rantai kognitifnya saat berkegiatan menggunakan LKS maka sebaiknya diawali dengan kegiatan melakukan observasi.

Selanjutnya dinyatakan oleh Carin \& Sund (1975) bahwa kegiatan pembelajaran sains di laboratorium perlu memperhatikan beberapa hal: (1) Permasalahan yang akan diinvestigasi, (2) Jenjang kelas, (3) Prinsip dan konsep apa yang akan dicapai, (4) Alat dan bahan apa yang diperlukan, (5) Pertanyaanpertanyaan untuk diskusi, (6) Aktivitas discovery yang dilakukan siswa, (7) Berfikir kritis dan proses sains yang dikembangkan, (8) Pertanyaan-pertanyaan yang bersifat open ended, dan (9) Catatan dan penjelasan guru. Dengan demikian tidak tepat jika dalam LKS hanya berisi topik dan langkah kerja atau justru hanya berupa sekumpulan soal-soal yang harus dijawab oleh siswa.

Menurut Supriatno (2013) mengenai tujuan, pendekatan dan prosedur serta materi pada desain kegiatan laboratorium harus memperhatikan hal-hal berikut : (1) tujuan kegiatan laboratorium bukan hanya menekankan pada aspek kognitif saja, tetapi juga aspek psikomotor untuk mengembangkan keterampilan dasar laboratorium. (2) jika menggunakan pendekatan deduktif dengan model ekspositori maka hanya dapat digunakan untuk melatih keterampilan-keterampilan manipulasi dan mengumpulkan data, tetapi tidak dapat digunakan untuk latihan merancang eksperimen. (3) dari aspek prosedur siswa diberikan kesempatan untuk merancang kegiatan ataupun melakukan memanipulasi variabel. (4)dari aspek pemilihan materi, kegiatan laboratorium yang dikembangkan harus mempertimbangkan essensi, kesesuaian, kedalaman dan kompleksitasnnya.

Terkadang kegiatan pratikum sering membuat siswa frustasi atau kurang mengerti terhadap kegiatan pratikum yang dilakukan. Hal ini menyebabkan ketidakbermaknaan dalam melakukan pratikum (Novak \& Gowin, 1985). Salah satu penyebab ketidakbermaknaan pratikum adalah desain kegiatan pratikum yang tidak dapat menjadi petunjuk yang tepat sehingga menyebabkan siswa tidak bisa mengkonstruk konsep, prinsip, dan teori serta kurang melibatkan proses berfikir siswa. Maka agar kegiatan laboratorium lebih efektif dan bermakna bagi siswa, guru perlu melakukan analisis penerapan kelayakan desain kegiatan laboratorium dan mau melakukan ujicoba sehingga dapat mengadopsi desain kegiatan laboratorium dengan cara mengadaptasi dan merekonstruksi. Akan lebih baik jika guru mampu merancang dan mengembangkan kegiatan laboratorium sendiri. 


\section{Rekonstruksi LKS Lembar Kegiatan Pratikum yang direkonstruksi : Cara Kerja Enzim}

\section{Kompetensi Dasar}

3.2 Memahami peran enzim dalam proses metabolisme dan menyajikan data tentang proses metabolisme berdasarkan hasil investigasi dan studi literatur untuk memahami proses pembentukan energi pada makhluk hidup.

4.2 Melaksanakan percobaan dan menyusun laporan hasil percobaan tentang cara kerja enzim, fotosintesis, respirasi anaerob secara tertulis dengan berbagai media.

\section{Tujuan}

1. Menyelidiki peranan enzim katalase

2. Menyelidiki faktor - faktor yang mempengaruhi kerja enzim

3. Mengetahui serta memahami reaksi - reaksi kimia yang terjdi pada pengujian enzim katalase

\section{Teori}

Enzim merupakan protein yang berperan sebagai katalis dalam metabolisme makhluk hidup. Enzim berperan untuk mempercepat reaksi kimia yang terjadi di dalam tubuh makhluk hidup, tetapi enzim itu sendiri tidak ikut bereaksi. Oleh sebab itu, enzim disebut sebagai salah satu katalisator alami. Enzim terdiri dari apoenzim dan gugus prostetik. Apoenzim adalah bagian enzim yang tersusun atas protein. Gugus prostetik adalah bagian enzim yang tidak tersusun atas protein. Gugus prostetik adalah bagian enzim yang tidak tersusun atas protein. Gugus prostetik dapat dikelompokkan menjadi dua yaitu koenzim (tersusun dari bahan organik) dan kofaktor (tersusun dari bahan anorganik).

Enzim katalase adalah salah satu jenis enzim yang umum ditemui didalam sel sel makhluk hidup. Enzim katalase berfungsi untuk merombak Hidrogen Peroksida $\left(\mathrm{H}_{2} \mathrm{O}_{2}\right)$ yang bersifat racun yang merupakan sisa/hasil sampingan dari proses metabolisme.

Apabila $\mathrm{H}_{2} \mathrm{O}_{2}$ tidak diuraikan dengan enzim ini, maka akan menyebabkan kematian pada sel - sel. Oleh sebab itu, enzim katalase untuk merombak $\mathrm{H}_{2} \mathrm{O}_{2}$ menjadi substansi yang tidak berbahaya, yaitu berupa air dan oksigen. Selain bekerja secara spesifik pada substrat tertentu. Enzim juga bersifat termolabil (rentan terhadap perubahan suhu) serta merupakan suatu senyawa golongan protein. Pengaruh temperatur terlihat sangat jelas, karena dapat merusak enzim dan membuatnya terdenaturasi seperti kebanyakan protein.

Enzim katalase termasuk enzim hidroperoksidase, yang melindungi tubuh dari senyawa - senyawa peroksida yang berbahaya. Penumpukan senyawa peroksida dapat menghasilkan radikal bebas, yang selanjutnya akan merusak membran sel dan kemungkinan menimbulkan penyakit kanker serta arterosklerosis. 


\section{Alat dan Bahan}
Alat :
1. 5(lima) buah tabung reaksi
2. Rak tabung reaksi
3. Pipet tetes
4. Tabung ukur
5. Gelas kimia $100 \mathrm{ml}$
6. Korek api
7. Kaki tiga
8. Lampu spiritus
9. Penjepit tabung
10. Lidi
11. Spatula
12. Pisau cutter
13. pinset
14. Tissue
15. Kertas label

\section{Bahan :}

1. Hati ayam segar

2. Larutan Hidrogen Peroksida $\left(\mathrm{H}_{2} \mathrm{O}_{2}\right) 20 \%$

3. Larutan Asam Klorida $(\mathrm{HCl}) 2 \mathrm{M}$

4. Larutan Natrium Hidroksida $(\mathrm{NaOH}) 2 \mathrm{M}$

5. Akuades

\section{Jalannya Eksperimen}

1. Siapkan 5 buah tabung reaksi dan berilah label 1, 2, 3, 4 dan 5 .

2. Masukkan $2 \mathrm{ml}$ larutan $\mathrm{H}_{2} \mathrm{O}_{2} 20 \%$ kedalam setiap tabung reaksi.Perhatian: Hindarkan kulit Anda dari larutan $\mathrm{H}_{2} \mathrm{O}_{2}$ karena dapat menyebabkan iritasi dan rasa gatal.

3. Potonglah hati menggunakan cutter dengan ukuran $1 \mathrm{~cm} \times 1 \mathrm{~cm}$ sebanyak 5 potong.

4. Masukkan potongan hati yang pertama kedalam gelas kimia $100 \mathrm{ml}$ yang telah berisi $50 \mathrm{ml}$ aquades dan rebuslah hingga mendidih di atas pembakar spiritus.

5. Angkatlah potongan hati yang sudah matang dengan menggunakan pinset, kemudian letakkan di atas tissue dan tunggu sampai dingin.

6. Setelah dingin masukkan potongan hati yang pertama ke dalam tabung reaksi 1 dengan menggunakan pinset, kemudian dorong dengan menggunakan spatula agar potongan hati terendam pada larutan $\mathrm{H}_{2} \mathrm{O}_{2}$.

7. Amati reaksi yang terjadi pada tabung reaksi 1 dan ukurlah tinggi gelembung yang dihasilkan, kemudian catat pada data eksperimen. 
8. Potongan kedua yang masih segar, masukkan ke dalam tabung reaksi 2 dengan menggunakan pinset dan dorong dengan spatula.

9. Amati reaksi yang terjadi pada tabung reaksi 2 dan catat pada data eksperimen.

10. Potongan hati yang ketiga di potong menjadi 2 bagian yang sama besar, kemudian masukkan ke dalam tabung reaksi 3 dengan menggunakan pinset dan dorong dengan spatula.

11. Amati reaksi yang terjadi pada tabung reaksi 3 dan catat pada data eksperimen.

12. Tetesi sebanyak 5 tetes $\mathrm{NaOH}$ ke dalam tabung 4, kemudian masukkan potongan hati yang keempat dengan menggunakan pinset dan dorong dengan spatula.

13. Amati reaksi yang terjadi pada tabung reaksi 4 dan catat ke dalam data eksperimen.

14. Tetesi sebanyak 5 tetes $\mathrm{HCl}$ ke dalm tabung 5 , kemudian masukkan potongan hati yang kelima dengan menggunakan pinset dan dorong dengan spatula.

15. Amati reaksi yang terjadi pada tabung reaksi 5 dan catat pada data eksperimen.

16. Uji kandungan oksigen pada masing - masing tabung reaksi dengan cara memasukkan lidi yang ujungnya terdapat bara api ke dalam gelembung yang dihasilkan pada masing - masing tabung reaksi.

17. Amati nyala apinya dan catat ke dalam data eksperimen.

\section{Data Eksperimen}

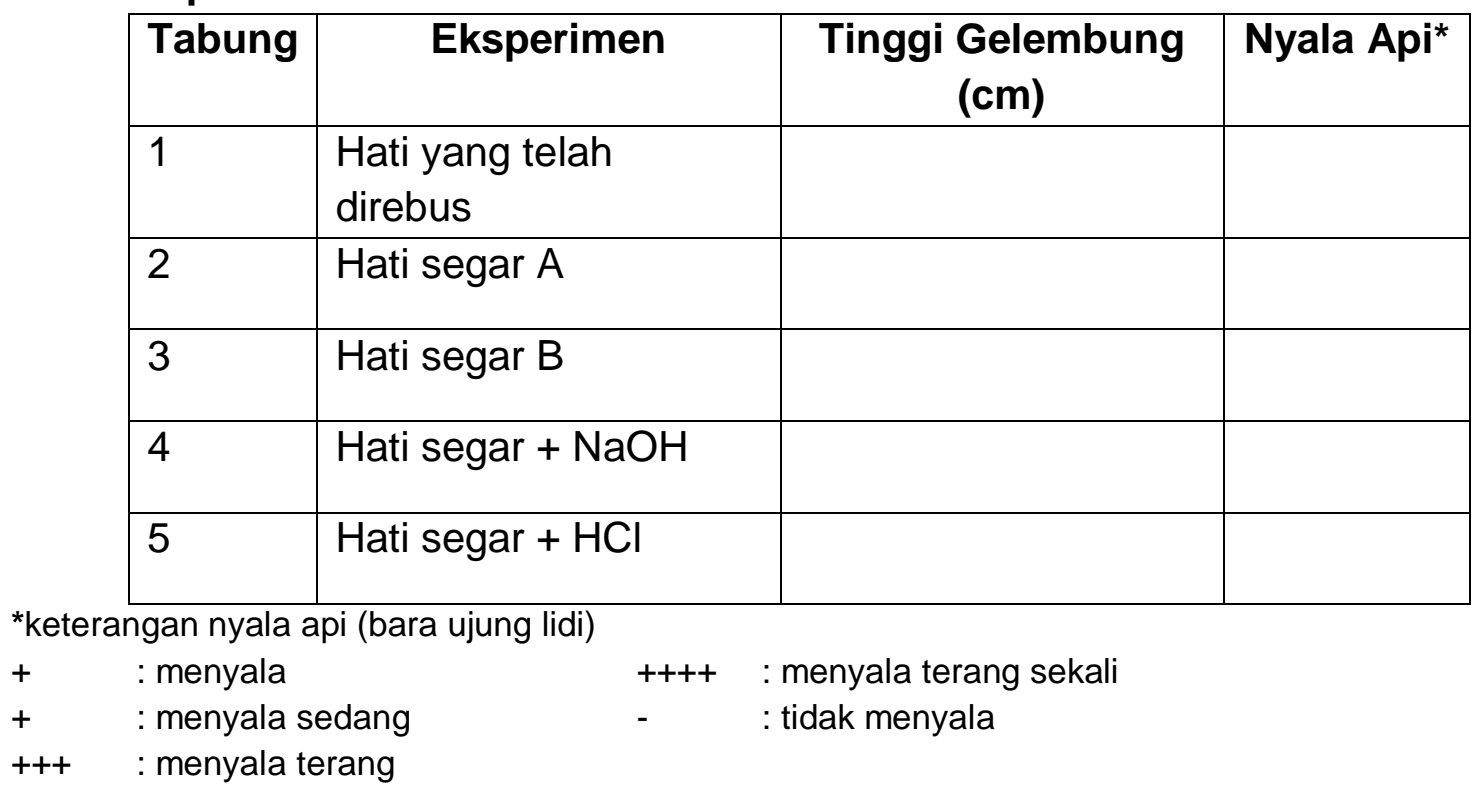

\section{Pertanyaan}

1. Pada tabung nomor berapakah hati ayam yang tidak terjadi reaksi kimia? Mengapa demikian?

2. Diantara tabung - tabung yang di dalamnya terjadi reaksi kimia, pada tabung manakah yang reaksi kimianya paling cepat? Mengapa demikian?

3. Pada perlakuan manakah pembentukan gelembung gas paling tinggi? Mengapa demikian? 
4. Gas apakah yang terbentuk dari reaksi tersebut? Jelaskan berdasarkan hasil percobaan!

5. Faktor apakah yang memengaruhi kerja enzim katalase? Jelaskan berdasarkan hasil percobaan!

6. Tuliskan dan jelaskan sifat - sifat enzim!

7. Sebutkan faktor - faktor yang mempengaruhi kerja enzim?

8. Bagaimana kesimpulan dari hasil percobaan yang Anda lakukan?

\section{KESIMPULAN}

Setelah dilakukan analisis konten petunjuk pratikum uji enzim katalase ditemukan bahwa desai kegiatan laboratorium atau lembar kerja siswa yang diterbitkan oleh beberapa penerbit yang beredar di sekolah-sekolah belum memenuhi komponen-komponen LKS yang lengkap. Judul, cara kerja, pertanyaan diskusi banyak yang kurang menuntun siswa untuk merekonstruksi konsep yang harus dicapai siswa, sehingga kegiatan pratikum tidak sesuai dengan tujuan pembelajaran yang diharapkan sesuai dengan Kompetensi Dasar kurikulum 2013. Maka perlu dilakukan rekonstruksi LKS agar kegiatan pratikum lebih bermakna bagi siswa sehingga konsep yang harus dikuasai siswa dapat tercapai.

\section{DAFTAR PUSTAKA}

Abrahams, I \& Millar, R. (2007). Does Practical Work Really Work? A study of the effectiveness of practical work as a teaching and learning method in school science. International Journal of Science Education.

Abrahams, I. (2009). Does practical work really motivate? A study of the affective value of practical work in secondary school science. International Journal of Science Education, 31(17), 2335-2353.

Arikunto, S. (2006). Metode Penelitian Kualitatif. Jakarta: Bumi Aksara

Carin A.A. \& Sund, R.B. 1975. Teaching Science Through Discovery. Third Ed.Columbus: Charles E Merrill PublishingCompany.

Carin A.A. \& Sund, R.B. (1989). Teaching Science Through Discovery. Sixth Ed.Columbus: Charles E Merrill PublishingCompany.

Collete, A.T. \& Chiappetta, EL. (1994). Science Instruction in the Middle andSecondary Scholls (Edisi ke-3). New York: Macmillan Publishing Company. Djohar. (1985). Menyongsong Pendidikan Biologi Tahun 2000. Naskah Pidato Pengukuhan

Jabatan. Yogyakarta: FKIE IKIP Yogyakarta.

Endang Widjajanti. (2008). "Kualitas Lembar Kerja Siswa". Makalah disampaikan dalam Kegiatan Pengabdian pada Masyarakat dengan Judul "Pelatihan Penyusunan LKS Mata Pelajaran Kimia Berdasarkan Kurikulum Tingkat Satuan Pendidikan bagi Guru SMK/MAK" di Ruang Sidang Kimia FMIPA UNY pada tanggal 22 Agustus 2008. 
Jokiranta, Kaisa. (2014). The Effectiveness of Practical Work in Science Education. University of Jyväskylä Department of Physics.

Laelasari, I. \&Supriatno, B. (2018). Analisis Komponen Penyusun Desain Kegiatan Laboratorium Bioteknologi. Universitas Ahmad Dahlan Jurnal Bioedukatika.

Lawson, A. E. (1995). Science Teaching and the Development of Thinking. WadsworthPublishing Company, Belmont, California.

Millar, R. (2004). The Role Of Practical Work In The Teaching And Learning Of Science. Washington DC. National Academy off Sciences.

Novak and Gowin. (1985). Learning How to Learn. New York: Cambridge University Press

Nasution, (2002). Metode Research : Penelitian ilmiah, Jakarta, PT.Bumi Aksara.

Rohaeti, El dkk. (2009). Pengembangan Lembar Kerja Siswa (LKS) Mata Pelajaran Sains Kimia Untuk SMP Kelas VII, VIII, dan IX. Artikel Penelitian FMIPA UNY.

Rezba, R.J., Sparague, C.S., Fiel, R.L., Funk, H.J., Okey, J.R., \& Jaus, H.H. (1995). Learning And Assessing Science ProcessSkills. 3rd ed. lowa: Kendall/Hunt Publishing Company.

Reece, J.B. et al. (2011). Campbell Biology. Ninth Edition. Boston: Benjamin Cummings.

Rustaman, A. \& Wulan, A. R. (2007). Strategi Pembelajaran Biologi. Bandung: Universitas Terbuka.

Sani, S.S., (2014). Teachers' Purposes And Practices In Implementing Practical Work At The Lower Secondary School Level. Procedia - Social and Behavioral Sciences 116 (2014) $1016-1020$

Sharpe, R. \& Abrahams, I. (2019). Secondary School Students' Attitudes To Practical Work In Biology, Chemistry And Physics In England, Research in Science \& Technological Education.

Suyanto, S., Paidi., \& Wilujeng, I. (2011). Lembar Kerja Siswa (LKS). Makalah disampaikan dalam acara Pembekalan SM3T (Sarjana Mengajar di Daerah Terpencil, Terluar, dan Tertinggal) di Akademi Angkatan Udara Yogyakarta tanggal 26 Nopember-6 Desember 2011.

Sedumedi, Thomas, D.T. (2017). Practical Work Activities as a Method of Assessing Learning in Chemistry Teaching. EURASIA Journal of Mathematics Science and Technology Education.

Supriyatno, B. (2013). Pengembangan Program Perkuliahan Pengembangan Pratikum Biologi Sekolah Berbasis ANCORB untuk Mengembangkan Kemampuan Merancang dan Mengembangkan Kemampuan Merancang dan Mengembangkan Desain Kegiatan Laboratorium. Disertasi Jurusan Penidikan Biologi FMIPA UPI: Tidak diterbitkan.

Swami \& Shields. (2006). Gowin's Knowledge Vee: Using To Improve Preservice Teachers Ability for Conducting and Directing Science.

Trianto. (2007). Model Pembelajaran Terpadu dalam Teori dan Praktek. Jakarta: Prestasi Pustaka. 
Wahidah, N.S., Supriyatno, B., Kusumastuti, M.N. (2018). Analisis Struktur dan Kemunculan Tingkat Kognitif pada Desain kegiatan Laboratorium Materi Fotosintesis. Assimilation: Indonesian Journal of Biology Education.

Wei, B.\& Li, X. (2017). Exploring Science Teachers' Perceptions Experimentation: Implications For Restructuring School Practical Work, International Journal of Science Education. 